\section{RECOVERY OF POTASH FROM IRON BLAST FURNACES AND CEMENT KILNS BY ELECTRICAI PRECIPITATION}

By LINN BRADLEx, of the Research Corporation, New York City

The subject of potash recovery is becoming of more universal interest to the public as well as to the technical man. The daily press and the magazines frequently refer to what is being done and to what should be done in this country in order to offset and decisively defeat the Kaiser and his followers. Recently several news items and editorials have appeared in the metropolitan press calling our attention to what is being done in Fingland toward making their country independent of Germany, and it appears that the British Government has furnished large sums of money to assist in recovering potash from their iron blast-furnace gases. It is predicted that this source will enable England to obtain enough potash to equal her entire prewar importation from Germany. France is reported to be as keenly awake to the possibilities along this line and we may see the time when France will be recovering large quantities of potash from iron ores which Germany has made such strenuous efforts to control. However, it is not surprising that interest in potash should increase, when we consider that this is the one big economic weapon which Germany has relied upon to regain her place in the sun after the war. She boasts that all countries will have to depend on her for potash. She claims that other countries cannot produce potash to compete with that supplied by Germany. But in this, as in many other instances, her reasoning is based on lack of information as to facts and possibilities.

The recovery of potash in this country is making rapid strides. The industry may be roughly divided into those plants in which the recovered potash is the main product and those in which the potash is recovered as a by-product. In this paper the latter phase will be considered, as it is believed that while the largest immediate tonnage may be obtained from desert lakes, kelp, alunite, and a few other sources, nevertheless a study of the economic problems will show that the surest way of making our potash industry a permanent and enduring one, able to supply all of our requirements, even against German competition, is to develop and rely upon the by-product potash.

After the installation of the Cottrell process at the plant of the Riverside Portland Cement Company in California was placed in operation for the purpose of eliminating the dust nuisance, it was noticed that the material collected in various parts of the precipitator differed in fineness. Natural inquisitiveness then called for an analysis of these products to determine if any impurities in the raw mix had become concentrated in any portion of the dust. The alkalies increased with the fineness of the material as shown by screen analyses. At that time considerable light fume was escaping from the precipitator exits and the suggestion was made and urged that some of this material be collected and analyzed as it might show even higher alkali content, since having been interested in agricultural and fertilizer problems it seemed to some of us that potash might be found in the escaping fume in percentages such as would warrant its recovery. This the first commercial potash-recovering plant in this country was. established. The engineer in charge of this work was W. A. Schmidt, of Los Angeles. Since that time a number of improvements have been developed and the commercial success of the potash plant at Riverside has been. the cause of several other cement companies installing potash recovery plants.

Early in I9 2 the Research Corporation, of New York, started to develop the Cottrell process and apply it to various plants in the eastern portion of the United States. Shortly after work had been begun, a paper was read and a demonstration given at a meeting of the local section of the AMERICAN CHEMICAL SOCIETY near Allentown, Pa. The next day arrangements were made for a visit to the South Bethlehem plant of the Bethlehem
Steel Company. Having in mind the experiences of the Riverside cement plant, curiosity was aroused by the appearance of the gases coming from the tall brick stack connected to the boilers. An investigation was undertaken by Mr. R. J. Wysor, and this resulted in extensive investigations thereafter to determine the possibility of cleaning these gases by the Cottrell process and recovering whatever of value could be obtained from the collected material. Mr. Wysor has published a very able and valuable article in the Transactions of the American Institute of Mining Engineers (I9I7) giving a great deal of data on ores, fluxes, slags, potash balances, and other items directly related to the recovery of potash as a by-product of blast furnaces. His paper probably served as an inspiration for much of the work which has been undertaken abroad.

Analyses of iron ores, cokes, limestones, and dolomites show a wide variation in potash content, and it is therefore advisable for one interested to make sure that his raw materials are sufficiently rich to warrant, a potash recovery plant. Furnaces which produce a large tonnage of slag per ton of iron on account of the iron content of the furnace charge will, of course, carry more potash into the slag than furnaces which produce a relatively small volume of slag, other things being equal, except for composition of the charge. Some iron ores carry as high as 60 per cent of iron and are practically devoid of potash. Some cokes have a low ash and are low in potash. Some limestones and some dolomites may be quite pure. If, therefore, the ores are uniform and properly prepared and the fuel and flux are properly proportioned, the slag volume will be small and the potash in the gases may likewise be negligible. On the other hand, if the iron ore carries as much as two or even one per cent of potash $\left(\mathrm{K}_{2} \mathrm{O}\right)$ and the coke ratio is high, and it and the flux contains as much as 0.25 to 0.50 per cent of potash, quite a large quantity of potash will be volatilized and carried off by the gases from which it can be recovered. The high temperature in the blast furnace and the length of time under treatment allows the silicates to be decomposed more readily than in a cement kiln where the temperatures are not so high. The potentialities of the by-product recovery from blast furnaces would, therefore, seem to surpass the possibilities of the Portland cement industry in this regard.

Numerous attempts have heretofore been made, to recover potash from silicate rocks. The investment and operating cost, especially for fuel, are hard to overcome if one endeavors to volatilize the potash and recover it and nothing else. It therefore seems that the best way to recover the potash from these silicates by heat treatment is to charge these silicates into existing furnaces along with the regular charge and recover the potash as a by-product, thus eliminating the investment and operating cost for new and separate furnaces. This would be profitable up to a certain point, beyond which, however, this practice would not be desirable.

Since the investigations referred to were begun at South Bethlehem, numerous other furnaces have been investigated and potash balances made. Iron ores have been found in abundance in Alabama which carry from $I$ to as high as 3 per cent in potash and carry enough iron to make them highly suitable for this purpose. The following tables show the results of one investigation:

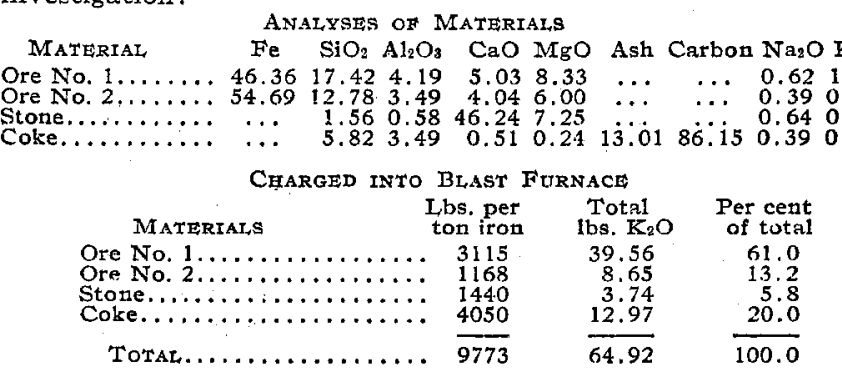


Summary

Total $\mathrm{K}_{2} \mathrm{O}$ charged into furnace per ton of iron pro-

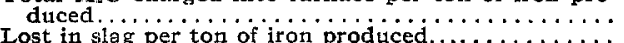
Lost in slag per ton of iron produced.................
Lost as fume from gas leaks per ton of iron produced Total potash recoverable from gases per ton of iron

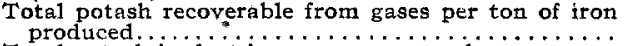
Total potash in dust it gases as per analyses...

Water-soluble potash in dust in gases as per analyses Portion of total potash in dust, which is water-soluble Total water-soluble potash recoverable per tou of iron by collecting the dust in the flue gases. $\ldots \ldots \ldots$.......
Total water-so:uble potash as above per 500 tons iron per day................................................ 350

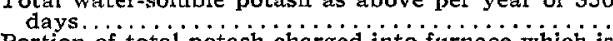
portion of total potash charged into furnace which is recoverable frota gases in water-soluble condition.. ting practice............................................... per year of 350 days.........................

A study of the above figures will show that it is desirable to keep the potash content of the raw materials up to the highest point and to keep the slag volume and potash content as low as possible. It is clear that if the slag volume remained constant, as well as its analysis, that if only I .6 lbs. of potash had been contained in the furnace charge there would have been nothing available for collection. With suitable slag volume and potash content and a rich potash charge the recovery of potash in quantities worth while is readily accomplished. Sodium chloride has been found helpful in liberating the potash in such way that it is recoverable in the dust in a water-soluble form. While working at a cupola furnace in which sash weights were made from old tin cans and other metal waste, it was found that the use of commion salt greatly increased the fume volume and density and this later was shown to be due to the fact that chlorides of lead, tin, and zinc were formed and readily volatilized as such. The use of salt has been extended to cement kiln practice and to other uses in connection with the recovery of silver, lead, and zinc from low-grade ores and tailings, the values being recovered from the gases after volatilization as chlorides.

Consideration of data such as presented in the tables given herein resulted in an effort being made to find raw materials suitable for making iron and yet carrying high percentages of potash. Samples of ores, fluxes, and cokes were obtained from a number of furnaces and other sources, and later on this work was carried on much more extensively by the Bureat of Soils of the Department of Agriculture and by the Bureau of Mines, Department of Interior. It is probable that Mr. Frederick Brown, of the Bureau of Soils, has now collected data on nearly all of the raw materials available for iron making and that if such data were made public in the near future, it would be of great assistance in connection with the problems under consideration. Personal efforts to find materials such as described developed the fact that in the eastern part of Alabama there is a very large tonnage of iron ores carrying in some cases an average of $I$ per cent of potash and in other instances an average of about $\mathrm{I} .80$ per cent of $\mathrm{K}_{2} \mathrm{O}$, several analyses showing a content of over 3 per cent of $\mathrm{K}_{2} \mathrm{O}$. - I am indebted to Dr. J. S. Grasty for having brought these ores to my attention and for much of the data on their iron and potash content as given later in this paper. Mr. M. W. Bush, president of the Shelby Iron Company, has also contributed data on the iron situation of the South and the values of these iron ores in furnace operations. I have examined these properties and have interviewed blast furnace operators who have used them in their furnaces and hold the opinion that they constitute an asset of importance to the nation as well as to interested parties. They should receive the consideration of the Government in connection with our war problems and likewise our post-war problems so as to assist in rendering our country absolutely independent of Germany. The ores carry an average of from 48 to 52 per cent of iron, are very uniform, easily mined and shipped as they are directly on the railroad, and operate satisfactorily in the furnace, producing good iron at low cost. Their potash content also acts as a desulfurizer, thus improving the grade of iron. The phosphorus content is very low.

The following table has been compiled to show the economic importance of these ores as a source of potash, the figures having been based on experience at several other furnaces as well as on the data obtained in connection with these particular ores and at various iron furnaces in the South. The table has been submitted to experienced iron blast-furnace operators for suggestions and criticisms. For comparison, other ores have been included in the table. The composition of the high-potash iron ore has been taken from the average of over rooo tons of such ore shipped to furnaces on which $\mathrm{K}_{2} \mathrm{O}$ was determined for each car of this particular shipment.

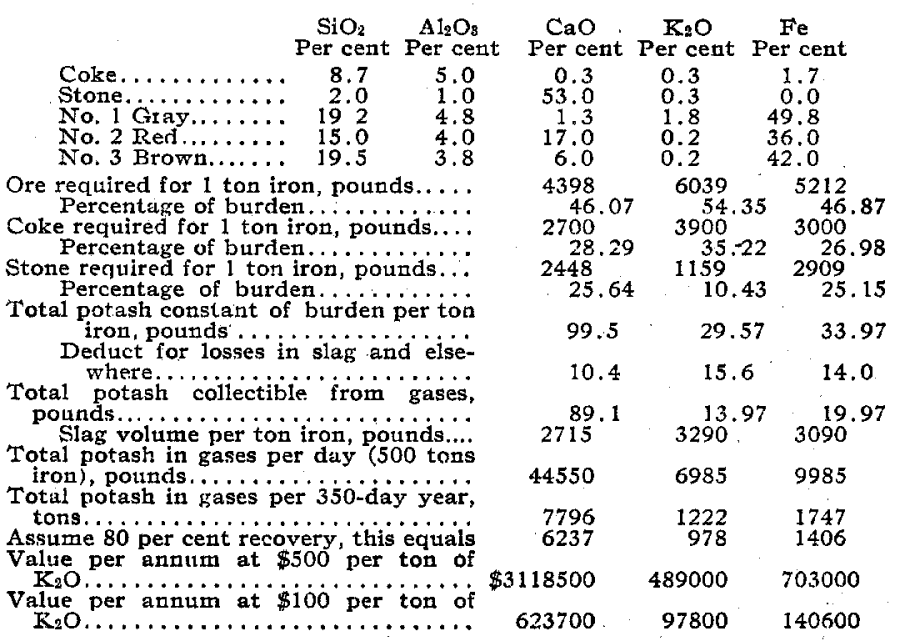

The total production of pig iron in this country is such that about 200 furnaces of such sizes as referred to above would be needed to meet our requirements if the furnaces were of the same capacity and the lower potash ores are used. Also it is easy to see that we now have sufficient furnace capacity to produce annually over $r, 500,000$ tons of potash, far in excess of our pre-war requirements, provided ores such as No. 1 are employed. The difficulty lies in the fact that we have not found that all furnace burdens carry the amount of potash shown under the No. I column. If the furnace charges and operations could be adapted so that one-fifth of the amount, or 300,000 tons, could be produced, this would meet our needs without assistance from any other source. The three constituents of the charge, ore, stone, and coke, contain more or less potash. By using those raw materials which carry more than usual amounts of potash, our recoveries can be considerably atgmented. In cases where ores are smelted which are excessively limey, feldspar, potash-bearing slate, or other potash-bearing silicates could be fed into the furnace and thus increase the potash content of the furnace burden.

Mr. H. E. Brown, a chemical engineer of New York City, has developed a process for making a special cement from the slag obtained from a blast furnace and at the same time recovering water-soluble potash from the gases. He charges limestone, coke, and feldspar into the furnace. Now if iron ores of suitable kind could be used for a portion of the raw material, it might be possible to produce potash from the gases, also pig iron, and a slag which could be readily converted into a marketable cement. As the market varies with the supply and price, the furnace charge could be varied so as to increase the potash and reduce the iron, or vice versa. The process has been developed to the extent that both potash and the special cement can be produced, but investigations looking to a reduction in the operating cost have not been completed. It appears, however, that with an assured market for the cement at fair prices, the process can be operated successfully and show a good return on the investment, 
especially when the price for potash is high. In this connection, it seems that consideration might well be given to the use of powdered coal introduced through the tuyères and thus reduce the coke required, possibly doing away with it altogether. It would materially reduce operating costs and increase production and recoveries.

It is natural to look to feldspar and other potash-bearing silicates for our potash. The cost of mining and grinding feldspar is one obstacle to be overcome which is not an obstacle for instance in the Cambrian slates of Georgia. It has been suggested also that efforts be made to recover potash from the tailings dumps in the Cripple Creek District of Colorado, these tailings carrying as high as 7 per cent of $\mathrm{K}_{2} \mathrm{O}$. Investigations as to the feasibility of this are now under way. Sufficient progress has not yet been made, however, to warrant any very optimistic statements. The fuel cost and the necessity for a long freight haul to the fertilizer-consuming districts are large items to overcome.

Serecites and Cambrian potash-bearing slates have been located in Georgia which carry potash in considerable quantity, several deposits analyzing as high as 8 or 9 per cent. Laboratory investigations have shown that the potash in these raw materials was more readily rendered water-soluble or volatilized by treatment with salt in a rotary kiln than the potash from feldspar. Furthermore, the amount of lime required to be added to the charge before the potash is liberated appears to be much less than required for feldspar. The cost of production is much less than in the case of feldspar and the cost of grinding is very much less and altogether these slates are much better adapted for the purpose here discussed than feldspar is. Dr. T. P. Maynard, of Atlanta, Georgia, who conducted these researches and developed the properties, reports that there is an enormous tonnage available. It is also reported that a company has been treating this material in a rotary kiln, adding 200 to 300 lbs. of salt per ton of raw material, volatilizing a good portion of the potash, and converting a large percentage of the balance into a water-soluble compound in the powdered calcines. One part limestone is used with two parts of ground slate. Freight rates should be very low since this material is located very close to a large market, namely, the cotton fields of Georgia and Alabama. Engineers state that cotton grows prolifically on these lands without any additional fertilizer, indicating the ease with which the potash is made available.

In all of the cases mentioned above, potash is volatilized and must be recovered.from the gases. The Cottrell process has met with excellent success in this phase of potash recovery problems. The field of application which has been developed the farthest is in the recovery of potash from cement kiln gases. Several plants are now in successful operation and at the present time a considerable tonnage is being obtained in this manner. Other plants are under construction and the outlook for a much larger tonnage is very favorable. In The American Fertilizer for August 3I, I9I8, John J. Porter, General Manager, Security Cement and Lime Company, of Hagerstown, Maryland, in an article entitled "The Recovery of Potash as a By-Product in the Manufacture of Portland Cement," gives a great deal of valuable information concerning this problem. The following is quoted from that article:

Estimating Potash Recovery-For the benefit of those who may wish to figure on their own conditions, I give the following method of calculating the probable recovery of potash.

Let $A=$ per cent potash in raw mix

Let $B=$ per cent potash in clinker

Let $\mathrm{C}=$ per cent liberation $=\frac{600 \mathrm{~A}-380 \mathrm{~B}}{600 \mathrm{~A}}$

Let $F=$ lbs. of potash recombined per bbl. clinker $(=0.7$ to I.5 depending on fuel consumption and per cent ash in coal)

Let $\mathrm{P}=$ per cent potash precipitated in treaters
Assume $600 \mathrm{lbs}$. of raw mix actually used to make one bbl. of clinker,

Then,

Lbs. of potash entering kilns per bbl. of clinker $=600 \mathrm{~A}$

Lbs. of potash volatilized in kilns per bbl. clinker $=600$ $\mathrm{AC}$

Lbs. of water-soluble potash entering treaters per bbl. clinker 600 AC-F

Lbs. of water-soluble potash collected in treaters per bbl. clinker $=(600 \mathrm{AC}-\mathrm{F})=\mathrm{P}$

The cost of collecting potash at Security is now running about as follows:

\begin{tabular}{|c|c|}
\hline & $\begin{array}{l}\text { Per Unit } \\
\text { of Potash }\end{array}$ \\
\hline 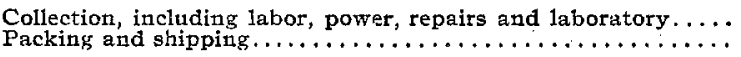 & $\begin{array}{l}\$ 0.14 \\
0.08\end{array}$ \\
\hline $\begin{array}{l}\text { Total operating cost, exclusive of depreciation, royalty, and salt } \\
\text { addition } \ldots \ldots \ldots \ldots \ldots \ldots \ldots \ldots \ldots \ldots \ldots \ldots\end{array}$ & $\$ 0.22$ \\
\hline
\end{tabular}

The article then goes on to show that from a $3000-\mathrm{bbl}$. cement plant, the operating profit per annum on the potash alone comes to about $\$ 458,000$, the raw mix having 0.75 per cent of potash. The article is quite complete and those interested are referred to it for further details. The Bureau of Soils published the results of their survey of cement plants. The data given indicate that this industry can be counted on to furnish 80 , ooo to I00,000 tons of potash annually. By using materials which are higher in potash content, such as feldspar, serecite, or slate in part, the yield of potash can be materially increased. The additional cost for raw material should be weighed against the greater financial return from the plant operation as a whole and not allow first cost per ton of material to govern. The utilization of existing cement kilns and equipment for the manufacture of cement as a by-product, placing special emphasis on the potash yield and profits therefrom, should be urged by all citizens, and this should be more emphatically urged for the recovery of potash from blast-furnace gases. The feat of obtaining all of our potash from existing industries by recovering the by-products will be typically American and worthy of our "Yankee ingenuity." The by-product method will enable us to compete with potash from any other source, and the Kaiser's vain boast that all countries will be compelled to submit to his will because they must have his potash, shall receive its proper answer. It is not difficult to recall that the by-products of our packing house industries constitutes the source of a large tonnage of our fertilizers, whereas a few years ago these materials were annoying left-overs, difficult to dispose of.

Referring again to the iron industry and its relation to the potash question, it should be pointed out that in the Alabama district there is an abundance of excellent coal, labor is plentiful and cheap, and the climatic conditions are such that the district. may be considered an all-year one as far as operating is concerned. Then when it is realized that there is immediately at hand an enormous tonnage of high-grade iron ore which carries such a large potash content and that the South produces our cotton and therefore is the large consumer of potash and thus provides a large market within a few miles, the economic importance of this situation can be better appreciated. Other iron ores contain potash, some of which may justify recovery plants, and we should be on the lookout for such material, keeping in mind that our goal is to obtain our potash as a by-product at such a cost as will enable us to ignore Germany forever and thus make the dreams of the American chemist and engineer come true.

The South produces pig iron cheaper than any other district in normal times. In fact their furnaces must do this in order to stay in the market. The South does not yet consume as much iron and steel products as its population justifies and therefore their iron must carry a high freight charge if it is 
shipped North to the larger markets. The manufacture of cast iron pipe has, however, grown to a large industry. In the future more and more iron and steel will be consumed locally as it is evident that the South is coming into its own very rapidly. The additional profit which can be obtained from the potash will be of great assistance in keeping their iron furnaces in blast when the market sags. The South has a very fortunate combination of labor, raw materials, climate, and a large and near fertilizer market.

In France and in Great Britain the national governments have taken an active interest in the possibilities along the lines herein pointed out. It has been reported that investigations, extending over a period of three years, have shown that Great Britain can produce enough potash to satisfy all her requirements. The British Potash Company, Limited, has recently been organ.ized for this purpose and the British Government has undertaken to provide at least half of the total capital required. The funds necessary for the enormous scale operations contemplated will be more than an individual would be anxious to supply in these times. Another reason is that the British Government is fully awake to the importance of the potash to their national interests. It does not seem that our own Government should falter or lag in this field, but on the contrary should immediately make comprehensive plans and take energetic action of such a character as will insure the proper solution of the problems under discussion. At the present time individuals shy at putting their money into a new enterprise which requires much labor and material without having adequate assurance that their efforts will meet with success. In order to do this, the full and continuing support of the Government must be had. Priorities, labor, material, and fuel allocation play an all-important part, and on top of this the new industry is handicapped by having to face an enormous taxation before the plant is fully paid for from earnings, and there is no positive assurance that potash will long remain above the pre-war level. Surely this situation should be corrected promptly. It seems ridiculous that the United States should be playing the rôle of food granary for ourselves and our Allies, also raising the cotton which is so necessary in connection with the war, and yet be doing nothing to provide the potash either for food purposes or for the cotton, except the limited and inadequate efforts due to private initiative. It ought to be emphasized that potash is a subject which should be understood and appreciated by everyone in the nation, and that it should be considered primarily from the national point of view. Does any one of us imagine that there is such ignorance of potash in Germany as exists among our own citizens? No, they have learned that potash is the big German raw material and economic weanon which they counted upon and are still counting on to help the Kaiser impose his will on you and on me. This must be defeated!

To all those who are assisting in the solution of the problem, I would state that we should soon take steps to solve our postwar problems. The question of the market conditions which will prevail is ever before us. Germany will do all within her power after peace is declared to break down that which will have been built up, the same as she has destroyed the beautiful cities of France. She will endeavor to regain control of the potash situation in this country. Even now she probably has her propaganda all prepared and ready for launching. One need not be surprised to learn that she has agents in the various Governmental departments and bureaus in Washington ever ready to interfere with efforts being made by our technical and business men. Even now we hear rumors to the effect that potash is not a plant food and is not needed for cotton, potatoes, and various other crops. Careful investigation of the southern cotton fields should be convincing evidence that this may be another piece of German propaganda. It is difficult to check up these rumors, but all of us should be on guard against these German efforts. It would be to the national interest in the broadest way for this country to take steps to forever exclude every ounce of German potash. Tariff, price control, and other methods should be earnestly considered. The farmer must be made to realize that he dare not use German potash even if he might obtain it a little bit cheaper than the local product. In other words he must not be a potash slacker. The politician hates to take any action which would have a harmful effect on the farmer vote, so we may look for strong opposition when legislation is urged for protection of the new potash industry. It will be short-sighted of our Congressmen to fail or neglect to fully protect this industry. It should be remembered that Germany will continually strive to break down any barriers which may have been erected, and it therefore behooves us to band ourselves together in an alliance which could fittingly be called the American Potash Alliance and see to it that our interests are at all times being taken care of. In unity there is strength, therefore let all parties interested form such an alliance and immediately organize and institute efforts to have the proper legislation passed, and also to conduct a publicity and an educational campaign throughout the country and, generally, to serve the combined interests of those who assist in rendering our country free from the Kaiser as far as potash is concerned. The hearty and active coopperation of the various technical societies should be readily obtained, and 1 commend these suggestions for the formation of the American Potash Alliance to their attention. The author would be pleased to hear from all who approve this suggestion.

\section{Articles from Miscellaneous Sources}

Gale, "Our Mineral Supplies-Potash," U. S. Geol. Surv., Bull. 666-N.

Gale, "Potash in r916-Part II," U. S. Geol. Surv., Mineral Resources of the United States, rgi6.

Ross, Merz and Wagner, "The Recovery of Potash as a ByProduct in the Cement Industry," U. S. Dept. Agr., Bull. 572. Porter, "The Recovery of Potash as By-Product in the Manufacture of Portland Cement." Paper presented at Chicago Meeting of the Portland Cement Association, Sept. Io to I3, I9I7.

Wysor, "Potash as a By-Product from the Blast Furnace," Trans. Am. Inst. of Mining Eng., 56, 257. To this article is appended a bibliography; also see discussion of article on pages 288--302.

Stockbridge, “The Potash Famine," World's Work, May I9I8.

"Potash in Maryland Becomes a Reality," Baltimore Morning Sun, May I8, rgi8.

Articles from Metallurgical and Chemical Engineering

Koepping, "Can an American Potash Industry be Established?" December I, I916.

de Beers, "Development of our Potash Industry," December I, I9I6.

"Glimpses of New Pacific Coast Industries in the Making," November I, I9I6.

"Potash from Cement Mills," June I, I9I7.

"Potash from Cement at Riverside Portland Cement Company, July I, I9I7.

Meade, "Possibilities of Developing an American Potash Industry," July I5, I9I7.

Buck, "Bibliography on the Extraction of Potash from Complex Minerals-Feldspar, Leucite, etc.,' January I, Igr8.

\section{Articles from "This Journal"}

Haff and Schwartz, "A Practical Revision of the Cobalt Nitrate Method for the Determination of Potash," August igI 7.

Ross and Merz, "Recovery of Water-Soluble Potash as a ByProduct in the Cement Industry," November I9I7.

Anderson and Nestell, "The Volatilization of Potash from Cement Materials," March I9r7. 
Articles from the Manufacturers Record

Catlett, "Possibilities in Potash Production from Fumes of Cement Kilns," February 24, I916.

Catlett, "The Blast Furnace as a Potash Producer," May I r, I9I6.

"Potash-Making Possible in Iron Production," May I r, I9 I6.

"Recovery of Potash at Security Cement Plant," May II, I9r6.

"Widespread Interest in Potash as By-Product in Iron Production," May i 8, igi6.

"Potash in Iron-Making as Viewed by Government Experts,"

May 25, I916. Also letter from Catlett in same issue.

"Bethlehem Company Saving Potash as By-Product," June 8, 1916.

Grasty, "Southern Iron Ores as a Source of Potash," September 14 , I9I6.

Burchard, "Potash as a By-Product in Cement and Iron Industries," September 14, I9 I6.

"Potash as a By-Product in Cement- and Iron-Making," March 22, I9I7.

Catlett, "Potash from Alabama Gray Ores," March 29, I917.

"Potash as a By-Product in Cement," August 26, I9I 7.

Wilmer, "Ioo,ooo Tons of Potash Obtainable from Cement

Dust Every Year," April 25, I918.

"Large Potash Recovery at Clinchfield Cement Plant," May 2, 19 r8.

Hicks, "Production of Potash in the United States," June 20 , I9I8.

Catlett, "Potash as a National Asset against Germany's Damnation Plans," July 4, I918.

"How We Can Become Wholly Independent of German Potash," August 15, 1918.

"American Potash for American Farmers," August 22, 1918.

"Potash Potentialities in America which if Utilized Would Make Us Independent of Germany," Open Letter to President, August 29, I918.

"Potash Question and Its Bearing upon Peace Terms," Letter from Dr. Maynard and Editorial Comment, September 5, IgI8.

See also the Manufacturers Record of September 12, 1918, and that of September 19, 19r8, for a number of articles on potash.

\section{POTASH FROM DESERT LAKES AND ALUNITE}

By J. W. Hornsey, Consulting Engineer, Summit, N. J.

The arbitrary action taken by the German government some years ago in forcing Americans who had purchased interests in German potash works to join the German Potash Syndicate and the lack of tact displayed by those who handled the situation for Germany, created so much ill feeling that altogether it brought about the determination upon the part of the United States Government and of American buyers to find some source of potash other than the German, and plans were thereupon made for both governmental and independent searches. Fortunately for this country when war was declared in I9I4 these searches had developed a large amount of valuable data.

Both the Geological Survey and the Bureau of Soils were granted appropriations and began active work which has proven to be of considerable value. The independent investigators made a somewhat more comprehensive survey without going quite so exhaustively into details, except where it seemed reasonably certain that a commercially workable supply would be found.

All probable sources of supply were investigated, including feldspar, kelp, desert lakes, leucite, and alunite. It was evident from the start that potash could not be produced profitably at ante-war prices from certain of these materials without the production and sale of by-products, and for some of these' by-products there was only a limited market. In other cases a some- what more careful study of the subject showed that potash was unquestionably the by-product.

This work has, however, definitely resulted in the development of a permanent potash industry in this country, and I say permanent advisedly. Some of the plants will, undoubtedly, be able to continue after the war.

\section{DESERT IAAKES}

Investigation of many of the lakes of western deserts showed such percentages of potash as to make it improbable that potash could be produced commercially in competition with Germany at the price then prevailing.

SEARLES LAKE-Early in rgi 2 a company which had acquired control of Searles Lake found that their deposit contained a considerable percentage of potash, apparently in the form of chloride. This so-called lake consists of a deposit of crystals, resulting from the evaporation of a prehistoric lake which was at least $600 \mathrm{ft}$. deep when it ceased to overflow. In the course of time, as evaporation under desert conditions continued, the lower portion of the valley became filled with crystals permeated with a saturated brine. This body of crystals has been exhaustively investigated by the drilling of wells and its limitations are now well known. This crystalline body, averaging $75 \mathrm{ft}$. deep, has an area of $25 \mathrm{sq}$. mi. That portion near the edge is covered with mud, but $12^{1 / 2}$ sq. mi. are uncovered, and here the crystal body is smooth, hard, and solid enough to carry any weight. It is, however, not dense, but composed of crystals varying in size from, say $1 / 4$ in. cubes, to the equivalent of 4 in. cubes. This mass of crystals is formed with openings and interstices between them, approximating 40 per cent of the contents of the crystal body.

This interstitial space is filled with a brine saturated with the salts of which the crystals are formed, comprising the chloride of potassium and the carbonate, borate, sulfate, and chloride of sodium. As these voids extend throughout the entire crystal body they form unobstructed channels through the deposit, and owing to the well-known principle of the diffusion of salts in solution, the brine is virtually uniform in composition through the entire crystal body. Analyses of many samples taken at widely separated points have given substantially the same result. The following is a typical analysis given in the form of the usual hypothetical combination, but which to-day in view of the large amount of work done on this deposit, can hardly be called hypothetical:

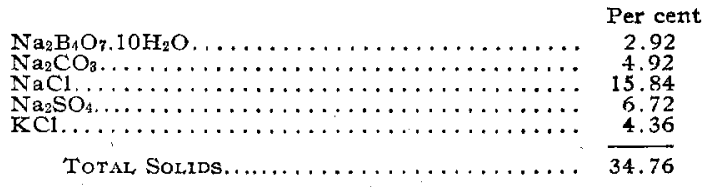

Repeated analyses of brine taken from various parts of the deposit by pumping continuously $24 \mathrm{hrs}$. per day for periods of 30 days show that near the center of the deposit the potash content calculated as $\mathrm{KCl}$ will gradually increase from about 4.75 per cent to 5.25 per cent. In one case at the end of 30 days it showed 5.40 per cent. Near the edge of the deposit the percentage gradually lowered from about 4.75 per cent to 4 , oo per cent.

A composite sample made up of 52 samples of the crystals taken from widely separated points and from various depths showed 5,00 per cent of potash calculated as $\mathrm{KCl}$. Obviously this shows the brine to be saturated with potash and before its potash content can be lowered by pumping, the potash in the crystals will be dissolved.

The average level of the brine is $I$ in. below the surface of the crystals, in consequence of which the surface crystals are always wet, and in the intensely hot desert atmosphere this is followed by a very high rate of the evaporation, which in turn is compensated for by a constant inflow of water from the sur- 